Check for updates

Cite this: RSC Adv., 2019, 9, 6762

Received 17th January 2019

Accepted 18th February 2019

DOI: $10.1039 / c 9 r a 00439 d$

rsc.li/rsc-advances

\section{Structural evolution of $\operatorname{LiN}_{n}{ }^{+}(n=2,4,6,8$, and 10) clusters: mass spectrometry and theoretical calculations $\dagger$}

\author{
Zhongxue Ge, ${ }^{\star a b}$ Kewei Ding, (DD ab Yisu Li, ${ }^{c}$ Hongguang Xu, ${ }^{d}$ Zhaoqiang Chen, ${ }^{c}$

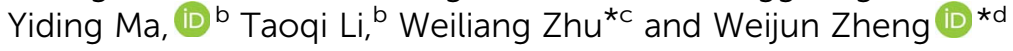

Mixed nitrogen-lithium cluster cations $\mathrm{LiN}_{n}{ }^{+}$were generated by laser vaporization and analyzed by time-offlight mass spectrometry. It is found that $\mathrm{LiN}_{8}{ }^{+}$has the highest ion abundance among the $\mathrm{LiN}_{n}{ }^{+}$ions in the mass spectrum. Density functional calculations were conducted to search for the stable structures of the $\mathrm{Li}-\mathrm{N}$ clusters. The theoretical results show that the most stable isomers of $\mathrm{LiN}_{n}{ }^{+}$clusters are in the form of $\mathrm{Li}^{+}\left(\mathrm{N}_{2}\right)_{n / 2}$, and the order of their calculated binding energies is consistent with that of $\mathrm{Li}-\mathrm{N}_{2}$ bond lengths. The most stable structures of $\mathrm{LiN}_{n}{ }^{+}$evolve from one-dimensional linear type $\left(C_{\infty \mathrm{v}}, n=2 ; D_{\infty}, n\right.$ $=4)$, to two-dimensional branch type $\left(D_{3 h}, n=6\right)$, then to three-dimensional tetrahedral $\left(T_{\mathrm{d}}, n=8\right)$ and square pyramid $\left(C_{4 v}, n=10\right)$ types. Further natural bond orbital analyses show that electrons are transferred from the lone pair on $\mathrm{N}_{\alpha}$ of every $\mathrm{N}_{2}$ unit to the empty orbitals of lithium atom in $\mathrm{LiN}_{2-8}{ }^{+}$, while in $\mathrm{LiN}_{10}{ }^{+}$, electrons are transferred from the bonding orbital of the $\mathrm{Li}-\mathrm{N}_{\alpha}$ bonds to the antibonding orbital of the other $\mathrm{Li}-\mathrm{N}_{\alpha}$ bonds. In both cases, the $\mathrm{N}_{2}$ units become dipoles and strongly interact with $\mathrm{Li}^{+}$. The average second-order perturbation stabilization energy for $\mathrm{LiN}_{8}{ }^{+}$is the highest among the observed $\mathrm{LiN}_{n}{ }^{+}$clusters. For neutral $\mathrm{LiN}_{2-8}$ clusters, the most stable isomers were also formed by a $\mathrm{Li}$ atom and $n / 2$ number of $\mathrm{N}_{2}$ units, while that of $\mathrm{LiN}_{10}$ is in the form of $\mathrm{Li}^{+}\left(\mathrm{N}_{2}\right)_{3}\left(\eta^{1}-\mathrm{N}_{4}\right)$.

\section{Introduction}

Nitrogen clusters have been predicted to be potential high energy density materials (HEDM) $)^{1,2}$ by numerous theoretical ${ }^{3,4}$ studies. Since the identification of $\mathrm{N}_{5}^{+}, \mathrm{N}_{4}$, and $\mathrm{N}_{5}{ }^{-, 5-7}$ the search for new polynitrogen species by a variety of experimental techniques has received intense attention. However, only a few efforts have been successful due to the low stability of these clusters. Metal doped nitrogen clusters $\mathrm{MN}_{n}$ have advantages in designing new polynitrogen structural groups because the metal-nitrogen interactions may be able to stabilize polynitrogen groups in $\mathrm{MN}_{n}$ with respect to the corresponding isolated $\mathrm{N}_{n}$ species. $^{8}$ Many novel polynitrogen structural groups such as cyclic $\mathrm{N}_{4},{ }^{9-12} \mathrm{~N}_{5},{ }^{13} \mathrm{~N}_{6},{ }^{14}$ and $\mathrm{N}_{7}$ (ref. 15) have been predicted to exist in this form. Thus, it is interesting to generate metal-doped nitrogen clusters,

aState Key Laboratory of Fluorine \& Nitrogen Chemicals, Xi'an 710065, China ${ }^{b} X i^{\prime} a n$ Modern Chemistry Research Institute, Xi'an 710065, China. E-mail: gzx204@ sina.com.cn

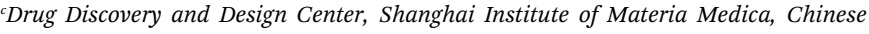
Academy of Sciences, Shanghai 201203, China. E-mail:wlzhu@mail.shcnc.ac.cn

${ }^{d B}$ Beijing National Laboratory for Molecular Sciences (BNLMS), State Key Laboratory of Molecular Reaction Dynamics, Institute of Chemistry, Chinese Academy of Sciences, Beijing 100190, China. E-mail: zhengwj@iccas.ac.cn

$\dagger$ Electronic supplementary information (ESI) available: Similar mass spectra and NBO data of the Li-N clusters. See DOI: 10.1039/c9ra00439d gradually increase their nitrogen content and study their structural characteristics.

To date, extensive experimental works have been undertaken to investigate mixed nitrogen-metal clusters. Numerous homoleptic azides of the type $\mathrm{M}\left(\mathrm{N}_{3}\right)_{n}(\mathrm{M}=\mathrm{Ti}, \mathrm{Nb}, \mathrm{Ta}, \mathrm{Mo}, \mathrm{W}, \text { etc. })^{16-27}$ and their derived salts have been prepared and characterized to understand the properties of highly energetic materials. $\mathrm{Nb}^{+}\left(\mathrm{N}_{2}\right)_{n}$ and $\mathrm{V}^{+}\left(\mathrm{N}_{2}\right)_{n}$ complexes were investigated using photodissociation spectroscopy. ${ }^{28,29} \mathrm{Rh}\left(\mathrm{N}_{2}\right)_{4}{ }^{+}$complexes were studied by infrared laser photodissociation spectroscopy and theoretical calculations. ${ }^{30} \mathrm{TiN}_{12}{ }^{+}$was generated by laser ablation, and the most stable structure was found to be $\mathrm{Ti}\left(\mathrm{N}_{2}\right)_{6}{ }^{+}$with $O_{\mathrm{h}}$ symmetry. ${ }^{31}$ The $\mathrm{VN}_{n}{ }^{+}(n=8,9$, and 10) clusters were generated and their most stable isomers were found to be in the form of $\mathrm{V}\left(\mathrm{N}_{2}\right)_{4}{ }^{+},\left(\eta^{2}-\mathrm{N}_{4}\right)$ $\mathrm{V}^{+} \mathrm{N}\left(\mathrm{N}_{2}\right)_{2}$ and $\left(\eta^{4}-\mathrm{N}_{4}\right) \mathrm{V}^{+}\left(\mathrm{N}_{2}\right)_{3}$, respectively. ${ }^{32}$

Lithium is the lightest metal. It is highly reactive and can react with nitrogen gas to form lithium nitride. ${ }^{33}$ In addition, lithium atoms have been successfully used as dopants in many clusters, such as silicon, ${ }^{34}$ germanium, ${ }^{35}$ boron $^{36}$ and aluminum $^{37}$ clusters, to tailor their structural and electronic properties. Although the experimental studies on lithiumdoped nitrogen clusters were very scarce, these clusters have been investigated in preliminary studies by many theoretical calculations. Cheng and Li predicted that lithium and $\mathrm{N}_{4}{ }^{2-}$ ring could form bipyramidal $\mathrm{Li}_{2} \mathrm{~N}_{4}$ structures ${ }^{38}$ with significant barriers for isomerization and dissociation. Glukhovtsev and 
Schleyer studied the structure and stability of $\mathrm{N}_{5} \mathrm{Li}$ and found that $\mathrm{N}_{5} \mathrm{Li}$ favours a planar $C_{2 \mathrm{v}}$ structure. ${ }^{39}$ Investigation of lithium-nitrogen clusters may provide useful information for understanding the lithium-nitrogen interactions and for the design of high nitrogen content species.

In this work, we investigated lithium-nitrogen binary clusters by laser ablation experiments coupled with theoretical calculations to gain insights into the geometric structures and electronic properties of $\mathrm{LiN}_{n}{ }^{+}$and their neutral counterparts.

\section{Experimental and theoretical methods}

\subsection{Experimental method}

The experiments were conducted using a home-built apparatus equipped with a laser vaporization supersonic cluster source and a reflectron time-of-flight mass spectrometer (RTOF-MS) that has been described elsewhere. ${ }^{40}$ The laser vaporization source was cooled by liquid nitrogen. The disk targets made of LiCl, LiF, LiF/ZrN (mole ratio $4: 1$ ), LiF/AlN (mole ratio $2: 1$ ) or $\mathrm{LiF} / \mathrm{BN}$ (mole ratio $2: 1$ ) were used in the experiments to provide $\mathrm{Li}^{+}$ions. The $\mathrm{LiN}_{n}^{+}(n=2,4,6,8$, and 10) cluster cations were generated in the laser vaporization source by laser ablation the rotating and translating disk targets in $\mathrm{N}_{2}$ gas with the second harmonic of a nanosecond Nd:YAG laser (Continuum Surelite II-10). Nitrogen carrier gas with $\sim 4$ atm backing pressure was allowed to expand through a pulsed valve (General Valve Series 9) into the source to provide nitrogen and to cool the formed clusters. The typical laser power used in this work was approximately $10 \mathrm{~mJ}$ per pulse. The generated cluster cations were mass-analysed by the RTOF-MS.

\subsection{Theoretical methods}

The geometry optimization and frequency calculations were performed with Gaussian 09 program package using density functional theory (DFT) at the M06-2X/6-311+G(d,p) level. ${ }^{41-43}$ Every stationary point on the potential energy surface (PES) was confirmed to be local minimum-energy structure by all positive harmonic frequencies. The bond length of the $\mathrm{N}_{2}$ molecule was calculated to verify the accuracy of the theoretical method. The calculated $\mathrm{N}-\mathrm{N}$ bond length is about $1.090 \AA$, which is consistent with an experimental value of $1.097 \AA^{44}$ The binding energies of nitrogen to $\mathrm{Li}^{+/ 0}$ were calculated for each $\mathrm{LiN}_{n}^{+1}$ ${ }^{0}$ species. The binding energy is defined as:

$$
\begin{aligned}
& E_{\mathrm{b} 1}=2\left[E(\mathrm{Li})+n / 2 E\left(\mathrm{~N}_{2}\right)-E\left(\mathrm{LiN}_{n}\right)\right] / n \text { (for the neutrals) } \\
& E_{\mathrm{b} 2}=2\left[E\left(\mathrm{Li}^{+}\right)+n / 2 E\left(\mathrm{~N}_{2}\right)-E\left(\mathrm{LiN}_{n}^{+}\right)\right] / n \text { (for the cations) }
\end{aligned}
$$

To get further insight into the interactions between $\mathrm{N}_{2}$ molecule and $\mathrm{Li}^{+/ 0}$, we performed natural bond orbital (NBO) analysis ${ }^{\mathbf{4 5}}$ where the electronic wave function is interpreted in terms of a set of occupied Lewis orbitals and a set of unoccupied non-Lewis delocalized orbitals. For each donor NBO $(i)$ and acceptor NBO $(j)$, the stabilization energy $E_{2}$ associated with charge transfer $i \rightarrow j$ is given by

$$
E(2)=\Delta E_{i j}=q_{i} F(i, j)^{2} /\left(\varepsilon_{i}-\varepsilon_{j}\right)
$$

where $q_{i}$ is the donor orbital occupancy, and $\varepsilon_{i}$ and $\varepsilon_{j}$ are diagonal elements (orbital energies) and $F(i, j)$ is the off-diagonal NBO Fock matrix element.

The average $E(2)$ of $\mathrm{LiN}_{n}{ }^{+}$is defined as:

$$
\overline{E(2)}=2\left[\sum E(2)\right] / n
$$

\section{Experimental results}

Fig. 1 shows a typical mass spectrum of the clusters generated in the experiment with $\mathrm{LiCl}$ as the substrate and $\mathrm{N}_{2}$ as the carrier gas. It is observed that the main series of lithiumnitrogen clusters are $\mathrm{LiN}_{2}{ }^{+}, \mathrm{LiN}_{4}{ }^{+}, \mathrm{LiN}_{6}{ }^{+}, \mathrm{LiN}_{8}{ }^{+}$and $\mathrm{LiN}_{10}{ }^{+}$. The mass intensity of $\mathrm{LiN}_{8}{ }^{+}$is predominant compared to those of the other $\mathrm{LiN}_{n}^{+}$species. No mass peak of $\mathrm{LiN}_{n}^{+}$with odd numbers of nitrogen atoms has been detected. In addition to the mass peaks of lithium-nitrogen clusters, the mass peaks of $\mathrm{LiN}_{2}\left(\mathrm{H}_{2} \mathrm{O}\right)^{+}, \operatorname{LiN}_{4}\left(\mathrm{H}_{2} \mathrm{O}\right)^{+}, \operatorname{LiN}_{6}\left(\mathrm{H}_{2} \mathrm{O}\right)^{+}$and $\operatorname{LiN}_{8}\left(\mathrm{H}_{2} \mathrm{O}\right)^{+}$are also observed. The formation of $\operatorname{LiN}_{n}\left(\mathrm{H}_{2} \mathrm{O}\right)^{+}$more likely is due to the presence of trace amounts of water in the carrier gas. In laser ablation experiments with $\mathrm{LiF}, \mathrm{LiF} / \mathrm{ZrN}, \mathrm{LiF} / \mathrm{AlN}$ and $\mathrm{LiF} / \mathrm{BN}$ as substrates, similar lithium-nitrogen clusters were obtained (ESI, Fig. S1-S4†).

\section{Theoretical results}

To search for the stable structures of $\operatorname{LiN}_{n}{ }^{+}$and $\operatorname{LiN}_{n}(n=2,4,6,8$, and 10), we have conducted calculations for nine different categories of structures, from $\mathrm{LiN}_{2}$ to $\mathrm{LiN}_{10}$. Starting from the simplest one containing only two nitrogen atoms and a lithium atom, by adding one nitrogen atom at a time to the system, we obtained an increasing number of geometrical configurations as the system

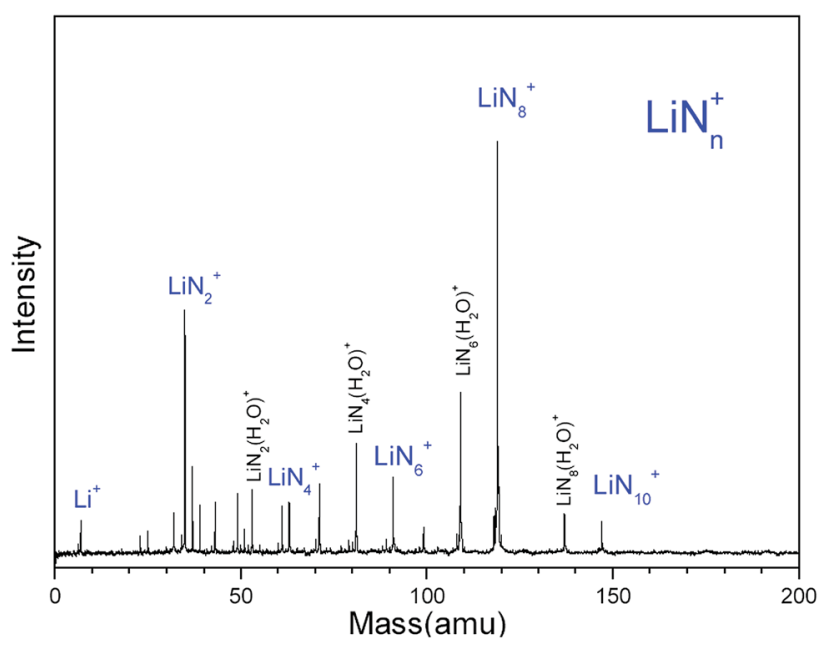

Fig. 1 Typical mass spectrum of $\mathrm{Li}-\mathrm{N}$ clusters generated by laser ablation of a $\mathrm{LiCl}$ target with $\mathrm{N}_{2}$ as the carrier gas. 
became larger. By placing the nitrogen atoms at different locations, we constructed the initial geometrical structures with a series of units such as $\mathrm{N}_{2}$ molecules, $\mathrm{N}_{3}$ chain and ring, $\mathrm{N}_{4}$ chain and ring, and $\mathrm{N}_{5}, \mathrm{~N}_{6}$, and $\mathrm{N}_{7}$ rings and so on containing lithium atoms. To ensure that the geometry optimizations located the true minima on the potential surfaces, frequency calculations were conducted for all optimized structures. For each initial geometrical configuration, we also considered many spin multiplicities $(2,4$, and 6 for neutral species and 1, 3, and 5 for positive ions). After full relaxation, a rather large number of low-lying isomers of $\mathrm{LiN}_{n}{ }^{+}$and $\operatorname{LiN}_{n}(n=2,4,6,8$, and 10) were found. Here, we show the typical isomers of $\operatorname{LiN}_{n}^{+}(n=2,4,6,8$, and 10) in Fig. 2 with the most stable structures on the left and those of $\operatorname{LiN}_{n}(n=2,4,6,8$, and 10) in Fig. 3.
$\mathrm{LiN}_{2}^{+}$

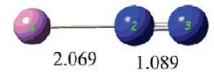

1A $C_{\text {oov }}$

$\Delta \mathrm{E}=0 \mathrm{kcal} / \mathrm{mol}$

$\mathrm{LiN}_{4}^{+}$

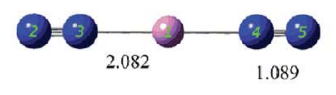

2A $D_{\infty h}$

$\Delta \mathrm{E}=0 \mathrm{kcal} / \mathrm{mol}$

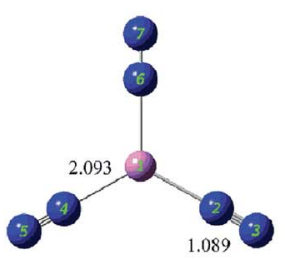

$3 \mathrm{~A} \quad D_{3 h}$

$\Delta \mathrm{E}=0 \mathrm{kcal} / \mathrm{mol}$

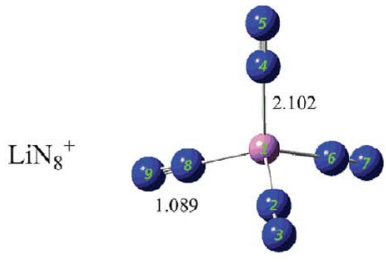

4A $T_{d}$

$\Delta \mathrm{E}=0 \mathrm{kcal} / \mathrm{mol}$

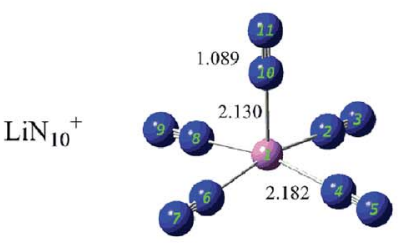

$5 \mathrm{~A} \quad C_{4 v}$

$\Delta \mathrm{E}=0 \mathrm{kcal} / \mathrm{mol}$

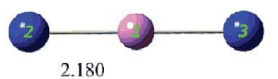

1B $D_{\propto c h}$

$\Delta \mathrm{E}=338.79 \mathrm{kcal} / \mathrm{mol}$

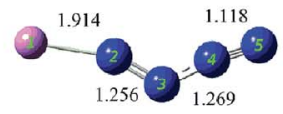

$2 \mathrm{~B} \quad \mathrm{C}_{\mathrm{s}}$

$\Delta \mathrm{E}=153.39 \mathrm{kcal} / \mathrm{mol}$

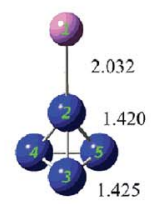

$2 \mathrm{C} \quad C_{3 v}$

$\Delta \mathrm{E}=186.98 \mathrm{kcal} / \mathrm{mol}$

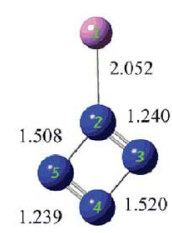

2D $C_{2 v}$ $\Delta \mathrm{E}=193.94 \mathrm{kcal} / \mathrm{mol}$

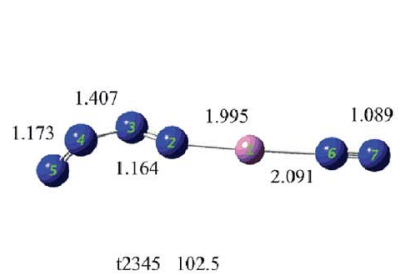

3B $\quad C_{1}$

$\Delta \mathrm{E}=159.57 \mathrm{kcal} / \mathrm{mol}$

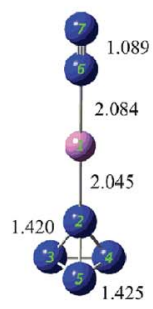

3C $C_{3 v}$

$\Delta \mathrm{E}=185.59 \mathrm{kcal} / \mathrm{mol}$
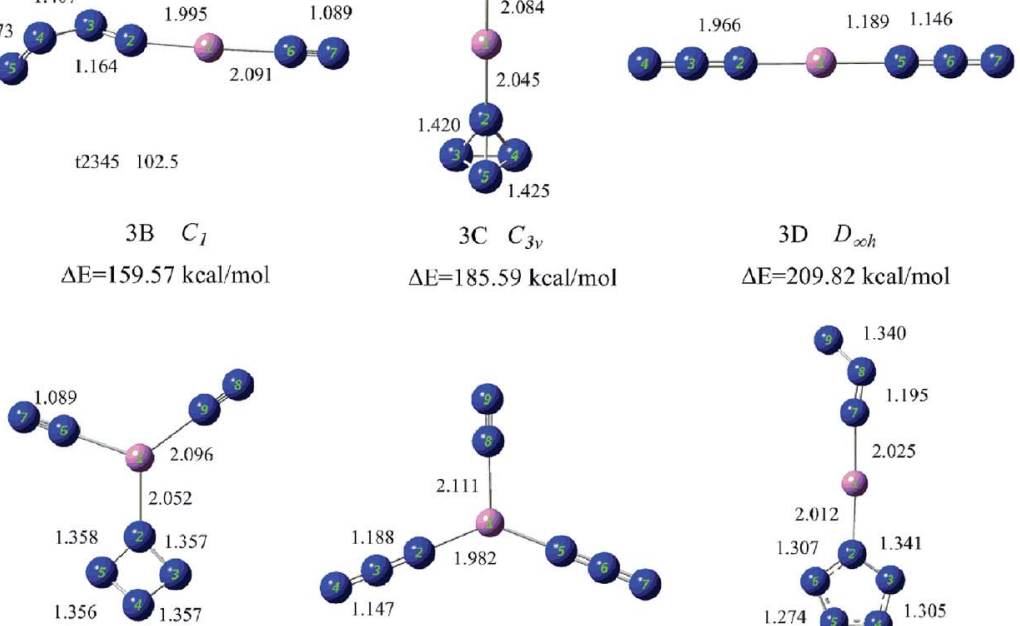

$4 \mathrm{~B} C_{1}$

$\Delta \mathrm{E}=208.52 \mathrm{kcal} / \mathrm{mol}$

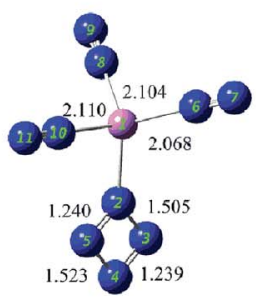

$5 \mathrm{~B} \quad C_{I}$

$\Delta \mathrm{E}=189.21 \mathrm{kcal} / \mathrm{mol}$

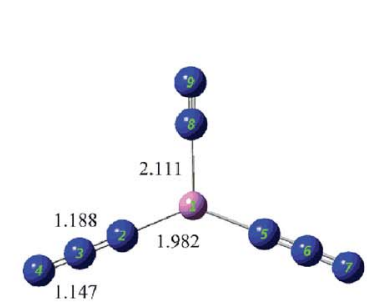

$4 \mathrm{C} \quad C_{2 \mathrm{v}}$

$\Delta \mathrm{E}=210.67 \mathrm{kcal} / \mathrm{mol}$

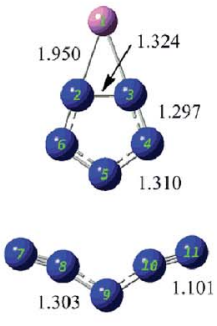

$5 \mathrm{C} C_{2 v}$

$\Delta \mathrm{E}=275.79 \mathrm{kcal} / \mathrm{mol}$
3D $D_{\infty h}$ $\Delta \mathrm{E}=209.82 \mathrm{kcal} / \mathrm{mol}$

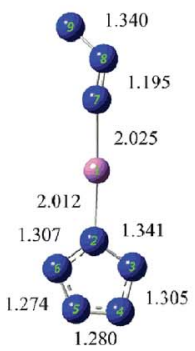

$4 \mathrm{D} C_{I}$

$\Delta \mathrm{E}=333.21 \mathrm{kcal} / \mathrm{mol}$

Fig. 2 Typical low-lying isomers of $\operatorname{LiN}_{n}{ }^{+}(n=2,4,6,8$, and 10) clusters. The bond lengths are given in angstroms. 


\subsection{Structures of $\mathrm{LiN}_{2}^{+}$and $\mathrm{LiN}_{2}$}

The ground state structure of $\mathrm{LiN}_{2}^{+}(1 \mathrm{~A})$ is a $C_{\infty \mathrm{v}}$ symmetry linear structure formed by attaching an end-on $\mathrm{N}_{2}$ molecule to a Li atom. The $\mathrm{N}-\mathrm{N}$ bond lengths in the $\mathrm{N}_{2}$ unit are $1.089 \AA$. The second isomer (1B) is a $D_{\infty \mathrm{h}}$ symmetry linear structure formed by inserting a Li atom between two $\mathrm{N}$ atoms. It is much higher in energy than $1 \mathrm{~A}$.
For neutral $\mathrm{LiN}_{2}$, the most stable isomer $1 \mathrm{~A}^{\prime}$ has a $C_{2 \mathrm{v}}$ symmetry triangular structure consisting of a side-on $\mathrm{N}_{2}$ molecule and an $\mathrm{Li}$ atom. The $\mathrm{N}-\mathrm{N}$ bond length in the side-on $\mathrm{N}_{2}$ unit is $1.168 \AA$, which is longer than that of isolated $\mathrm{N}_{2}$ molecule. The second stable structure $1 \mathrm{~B}^{\prime}$ has one end-on $\mathrm{N}_{2}$ unit and one $\mathrm{Li}$ atom, similar to $1 \mathrm{~A}$ of $\mathrm{LiN}_{2}{ }^{+}$. However, the $\mathrm{N}-\mathrm{N}$ bond length in the end-on $\mathrm{N}_{2}$ unit increases to $1.386 \AA$.
$\mathrm{LiN}_{2}$

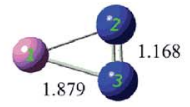

$1 \mathrm{~A}^{\prime} \quad C_{2 v}$

$\Delta \mathrm{E}=0 \mathrm{kcal} / \mathrm{mol}$

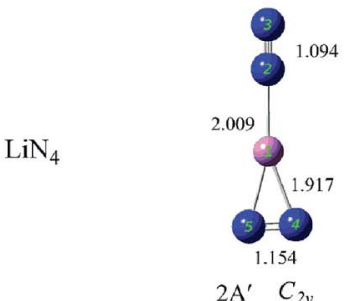

$\Delta \mathrm{E}=0 \mathrm{kcal} / \mathrm{mol}$

$\mathrm{LiN}_{6}$

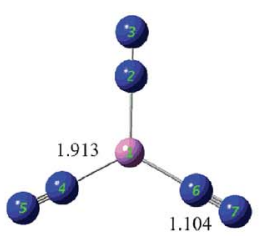

$3 \mathrm{~A}^{\prime} \quad C_{2 v}$

$\Delta \mathrm{E}=0 \mathrm{kcal} / \mathrm{mol}$

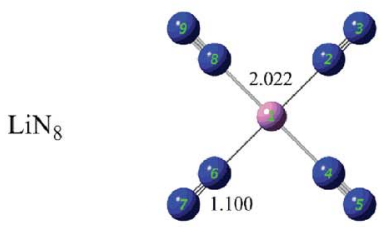

$4 \mathrm{~A}^{\prime} \quad D_{4 h}$

$\Delta \mathrm{E}=0 \mathrm{kcal} / \mathrm{mol}$

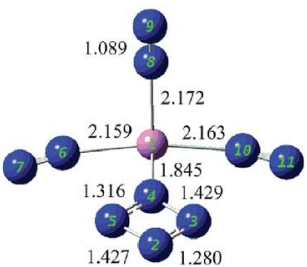

$5 \mathrm{~A}^{\prime} \quad C_{I}$

$\Delta \mathrm{E}=0 \mathrm{kcal} / \mathrm{mol}$
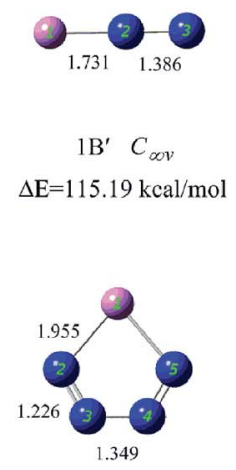

$2 \mathrm{~B}^{\prime} \quad C_{2 v}$

$\Delta \mathrm{E}=105.30 \mathrm{kcal} / \mathrm{mol}$

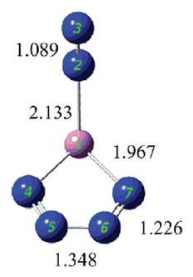

$3 \mathrm{~B}^{\prime} \quad C_{s}$

$\Delta \mathrm{E}=109.60 \mathrm{kcal} / \mathrm{mol}$

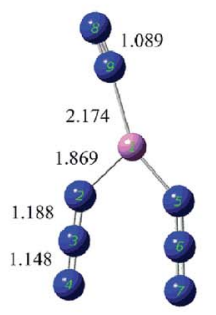

$4 \mathrm{~B}^{\prime} \quad C_{s}$

$\Delta \mathrm{E}=118.61 \mathrm{kcal} / \mathrm{mol}$

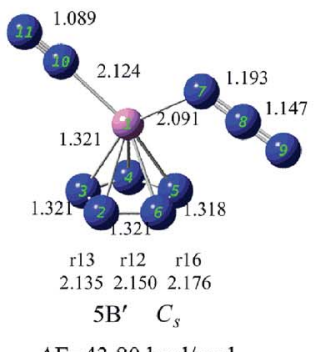

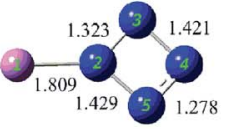

$2 \mathrm{C}^{\prime} \quad C_{s}$

$\Delta \mathrm{E}=117.49 \mathrm{kcal} / \mathrm{mol}$

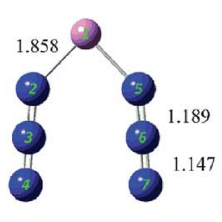

$3 \mathrm{C}^{\prime} \quad C_{2 v}$

$\Delta \mathrm{E}=116.84 \mathrm{kcal} / \mathrm{mol}$

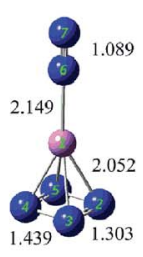

$3 \mathrm{D}^{\prime} \quad C_{2 v}$

$\Delta \mathrm{E}=120.14 \mathrm{kcal} / \mathrm{mol}$

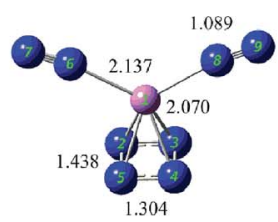

$4 C^{\prime} \quad C_{2 v}$

$\Delta \mathrm{E}=120.91 \mathrm{kcal} / \mathrm{mol}$

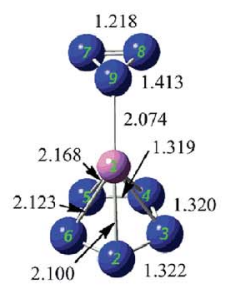

$4 \mathrm{D}^{\prime} \quad C_{s}$

$\Delta \mathrm{E}=196.30 \mathrm{kcal} / \mathrm{mol}$

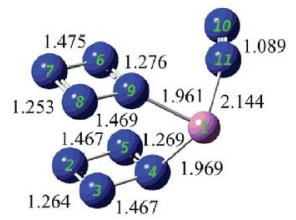

$5 \mathrm{C}^{\prime} \quad C_{1}$

$\Delta \mathrm{E}=178.67 \mathrm{kcal} / \mathrm{mol}$

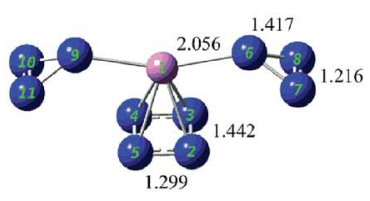

r14 $\mathrm{r} 15$

$5 \mathrm{D}^{\prime} \quad \mathrm{C}_{2}$

$\Delta \mathrm{E}=268.11 \mathrm{kcal} / \mathrm{mol}$

Fig. 3 Structures and relative energies of the low-lying isomers of neutral $\operatorname{LiN}_{n}(n=2,4,6$, 8, and 10) clusters. The bond lengths are given in angstroms. 


\subsection{Structures of $\mathrm{LiN}_{4}^{+}$and $\mathrm{LiN}_{4}$}

The ground state structure of $\operatorname{LiN}_{4}^{+}(2 \mathrm{~A})$ is a $D_{\infty \mathrm{h}}$ symmetry linear structure, in which two $\mathrm{N}_{2}$ molecules are attached directly to the central $\mathrm{Li}$ atom. The $\mathrm{N}-\mathrm{N}$ bond lengths in the $\mathrm{N}_{2}$ units are $1.089 \AA$ A. In the other low-lying isomers of $\mathrm{LiN}_{4}^{+}(2 \mathrm{~B}-2 \mathrm{D}), \mathrm{N}_{4}$ units were found and they interact with $\mathrm{Li}$ atoms as a whole. For example, in isomers $2 \mathrm{~B}, 2 \mathrm{C}$ and $2 \mathrm{D}$, the $\mathrm{N}_{4}$ units exhibit chain, tetrahedral, and cyclic configurations, respectively, and connect to Li atom via one nitrogen atom. These $\mathrm{N}_{4}$ units have been reported in many previous studies and the interaction between $\mathrm{Li}^{+}$and $\mathrm{N}_{4}$ ring was also predicted by $\mathrm{Li}$ et al. $^{\mathbf{3 8 , 4 6 - 4 8}}$

For neutral $\mathrm{LiN}_{4}$, isomer $2 \mathrm{~A}^{\prime}$ with one end-on and one sideon distances of the end-on and side-on $\mathrm{N}_{2}$ units are 1.094 and $1.154 \AA$, respectively. $\mathrm{A} \mathrm{N}_{4}$ chain is found in isomer $2 \mathrm{~B}^{\prime}$ and is connected to the $\mathrm{Li}$ atom through two terminal nitrogen atoms. Isomer $2 \mathrm{C}^{\prime}$ has a $\mathrm{Li}$ atom interacting with a $\eta^{1}-\mathrm{N}_{4}$ ring similar to isomer $2 \mathrm{D} \mathrm{LiN}_{4}{ }^{+}$. We could not find any isomer with a tetrahedral $\mathrm{N}_{4}\left(T_{\mathrm{d}}\right)$ unit in neutral $\mathrm{LiN}_{4}$.

\subsection{Structures of $\operatorname{LiN}_{6}^{+}$and $\operatorname{LiN}_{6}$}

For $\mathrm{LiN}_{6}{ }^{+}$, the lowest energy isomer (3A) has a planar structure with $D_{3 \mathrm{~h}}$ symmetry, in which three $\mathrm{N}_{2}$ molecules interact equally with the central Li atom via their terminal nitrogen atoms. The $\mathrm{N}-\mathrm{N}$ bond lengths in the $\mathrm{N}_{2}$ units are $1.089 \AA$. The low-lying isomers containing other all-nitrogen units are also found and their energies are much higher than that of $3 \mathrm{~A}$. Isomer $3 \mathrm{~B}$ has one end-on bound $\mathrm{N}_{2}$ molecule and one $\mathrm{N}_{4}$ chain coordinating to the Li atom via their terminal nitrogen atoms. The $\mathrm{N}_{4}$ chain can be regarded as a complex of two $\mathrm{N}_{2}$ sub-units because the bond linking the two $\mathrm{N}_{2}$ sub-units is relatively weak. Isomer $3 \mathrm{C}$ contains one end-on bound $\mathrm{N}_{2}$ molecule and one tetrahedral $\mathrm{N}_{4}$ unit that coordinates to the $\mathrm{Li}$ atom through one vertex nitrogen atom. Isomer $3 \mathrm{D}$ is a $D_{\infty \mathrm{h}}$ symmetry linear structure formed by attaching two $\mathrm{N}_{3}$ ligands to the $\mathrm{Li}$ atom.

The ground state structure of $\operatorname{LiN}_{6}\left(3 \mathrm{~A}^{\prime}\right)$ is similar to that of $\mathrm{LiN}_{6}{ }^{+}(3 \mathrm{~A})$. It was also formed by attaching three $\mathrm{N}_{2}$ molecules to the central $\mathrm{Li}$ atom, but its symmetry changes to $C_{2 \mathrm{v}}$. In the other low-lying isomers, $\mathrm{N}_{3}, \mathrm{~N}_{4}$ and $\mathrm{N}_{6}$ units are the main building blocks. Isomer $3 \mathrm{~B}^{\prime}$ contains one end-on bound $\mathrm{N}_{2}$ molecule and one $\mathrm{N}_{4}$ chain that connects to the $\mathrm{Li}$ atom through its two terminal nitrogen atoms. Isomer $3 \mathrm{C}^{\prime}$ has two end-on $\mathrm{N}_{3}$ units. Isomer $3 \mathrm{D}^{\prime}$ has one end-on $\mathrm{N}_{2}$ molecule and one $\eta^{4}-\mathrm{N}_{4}$ ring.

\subsection{Structures of $\mathrm{LiN}_{8}{ }^{+}$and $\mathrm{LiN}_{8}$}

The most stable structure of $\mathrm{LiN}_{8}{ }^{+}(4 \mathrm{~A})$ is a $T_{\mathrm{d}}$ symmetry structure formed by attaching four end-on $\mathrm{N}_{2}$ molecules to a $\mathrm{Li}$ atom. The $\mathrm{N}-\mathrm{N}$ bond lengths in the $\mathrm{N}_{2}$ units are $1.089 \AA$. The other low-lying isomers are much higher in energy than $4 \mathrm{~A}$. Isomer $4 \mathrm{~B}$ has one $\eta^{1}-\mathrm{N}_{4}$ ring and two end-on bound $\mathrm{N}_{2}$ molecules. Isomer $4 \mathrm{C}$ contains two $\mathrm{N}_{3}$ units and one end-on bound $\mathrm{N}_{2}$ molecule. $4 \mathrm{D}$ has one $\eta^{1}-\mathrm{N}_{5}$ ring and one $\mathrm{N}_{3}$ unit. The planar structure Li$\eta^{1}-\mathrm{N}_{5}$ in $4 \mathrm{D}$ was also studied by Glukhovtsev and considered as a possible isomer of $\mathrm{LiN}_{5} \cdot{ }^{39}$

For $\mathrm{LiN}_{8}$, the lowest energy isomer $\left(4 \mathrm{~A}^{\prime}\right)$ has a planar structure with $D_{4 \mathrm{~h}}$ symmetry in which four $\mathrm{N}_{2}$ molecules interact equally with the central $\mathrm{Li}$ atom via their terminal nitrogen atoms. The $\mathrm{N}-\mathrm{N}$ bond lengths in the $\mathrm{N}_{2}$ units are $1.089 \AA$ A. Isomer $4 \mathrm{~B}^{\prime}$ was formed by attaching two $\mathrm{N}_{3}$ units and one endon bound $\mathrm{N}_{2}$ molecule to a $\mathrm{Li}$ atom. Isomer $4 \mathrm{C}^{\prime}$ has one $\eta^{4}-\mathrm{N}_{4}$ ring and two end-on bound $\mathrm{N}_{2}$ molecules. Isomers $4 \mathrm{~B}^{\prime}$ and $4 \mathrm{C}^{\prime}$ could be considered to evolve from isomers $3 \mathrm{C}^{\prime}$ and $3 \mathrm{D}^{\prime}$ by the addition of one end-on bound $\mathrm{N}_{2}$ molecule. Isomer $4 \mathrm{D}^{\prime}$ has one $\eta^{5}-\mathrm{N}_{5}$ ring and one $\eta^{1}-\mathrm{N}_{3}$ units. This pyramidal structure formed by $\mathrm{N}_{5}$ ring and metal ions has been proposed in many theoretical studies..$^{39,49,50}\left[\mathrm{~N}_{3} \mathrm{MN}_{5}\right]^{q}$ structure was also calculated by Jin et al., and their results suggested that the $\left[\mathrm{N}_{3} \mathrm{MN}_{5}\right]^{q}$ in heterodecked form are thermodynamically more stable than the sandwich-like isomers $\left[\mathrm{N}_{4} \mathrm{MN}_{4}\right]^{q}\left(D_{4 \mathrm{~d}}\right)$ with even-membered $\mathrm{N}_{4}{ }^{2-} \operatorname{ring}[(\mathrm{M}, q)=(\mathrm{Ni}, 0),(\mathrm{Co},-1),(\mathrm{Fe},-2)] .^{51}$

\subsection{Structures of $\mathrm{LiN}_{10}^{+}$and $\mathrm{LiN}_{10}$}

The most stable isomer of $\operatorname{LiN}_{10}{ }^{+}(5 \mathrm{~A})$ consists of five $\mathrm{N}_{2}$ molecules placed around the $\mathrm{Li}$ atom and exhibits $C_{4 \mathrm{v}}$ symmetry. $5 \mathrm{~B}$ is the second stable structure and has three $\mathrm{N}_{2}$ molecules and one $\eta^{1}-\mathrm{N}_{4}$ ring and its energy is much higher than that of $5 \mathrm{~A}$. The third isomer $5 \mathrm{C}$ has one $\mathrm{N}_{10}$ unit consisting of an $\mathrm{N}_{5}$ ring and an $\mathrm{N}_{5}$ chain. This $\mathrm{N}_{10}$ unit was similar to the $\mathrm{N}_{5}{ }^{+} \mathrm{N}_{5}{ }^{-}$ionic compound. ${ }^{52}$ Isomer $5 \mathrm{D}$ is the fourth stable structure and has one $\eta^{1}-N_{5}$ ring, one $N_{2}$ and one $N_{3}$ unit.

The low-lying isomers of neutral $\mathrm{LiN}_{10}$ are different from those of its positive charged counterpart. As shown in Fig. 3, 5 $\mathrm{A}^{\prime}$ has three $\mathrm{N}_{2}$ molecules and one $\eta^{1}-\mathrm{N}_{4}$ ring. $5 \mathrm{~B}^{\prime}$ consists of one $\mathrm{N}_{2}$ molecule, one $\mathrm{N}_{3}$ unit and one $\eta^{5}-\mathrm{N}_{5}$ ring. It is higher in energy than $5 \mathrm{~A}^{\prime}$ by $43.80 \mathrm{kcal} \mathrm{mol}^{-1}$. Isomer $5 \mathrm{C}^{\prime}$ consists of two face-to-face $\eta^{1}-\mathrm{N}_{4}$ rings and one $\mathrm{N}_{2}$ unit. The adjacent $\mathrm{N}_{4}$ rings anchored on the $\mathrm{Li}$ atom in $5 \mathrm{C}^{\prime}$ are a precursor for the formation of other all-nitrogen structures. The most stable isomer with the $\mathrm{N}_{3}$ ring is $5 \mathrm{D}^{\prime}$ that has two $\eta^{1}-\mathrm{N}_{3}$ rings and one $\eta^{4}-\mathrm{N}_{4}$ ring. The nitrogen rings in $5 \mathrm{D}^{\prime}$ make it a highly energetic cluster.

\section{Discussion}

\subsection{Structure of $\mathrm{Li}-\mathrm{N}$ clusters}

In our experiments, it is found that $\mathrm{LiN}_{n}{ }^{+}$clusters $(n=2,4,6,8$, and 10) can be generated by laser ablation of $\mathrm{LiCl}$ without any solid nitrogen source, indicating that the carrier gas $\left(\mathrm{N}_{2}\right)$ used in the experiments participated in the formation of $\mathrm{Li}-\mathrm{N}$ clusters. The $\mathrm{LiN}_{n}{ }^{+}$clusters generated in our experiment all have even numbers of nitrogen atoms, suggesting that the generated $\mathrm{LiN}_{n}{ }^{+}$clusters may be formed by $\mathrm{N}_{2}$ sub-units.

As shown in Fig. 3, the most stable isomers of $\operatorname{LiN}_{n}^{+}(1 \mathrm{~A}-5 \mathrm{~A})$ obtained by theoretical calculations are formed by a lithium cation and a number of end-on bound $\mathrm{N}_{2}$ units, that is in the form of $\mathrm{Li}^{+}\left(\mathrm{N}_{2}\right)_{n / 2}$. This is consistent with the facts that the generated $\mathrm{LiN}_{n}{ }^{+}$cluster cations all have even number of nitrogen atoms and their numbers of nitrogen atoms differ by multiples of 2 . An examination of the most stable isomers $1 \mathrm{~A}-$ $5 \mathrm{~A}$ shows that the structures of these observed $\operatorname{LiN}_{n}{ }^{+}(n=2,4,6$, 8 , and 10) cluster cations evolve from one-dimensional linear type $\left(C_{\infty \mathrm{v}}, D_{\infty \mathrm{h}}\right)$ to two-dimensional branch type $\left(D_{3 \mathrm{~h}}\right)$ to threedimensional tetrahedral $\left(T_{\mathrm{d}}\right)$ and square pyramid $\left(C_{4 \mathrm{v}}\right)$ types 
Table 1 Binding energies and $\mathrm{Li}-\mathrm{N}_{2}$ distances of the most stable isomers of $\mathrm{LiN}_{n}{ }^{+/ 0}(n=2,4,6,8$, and 10)

\begin{tabular}{|c|c|c|c|c|c|c|c|c|c|c|c|}
\hline $\begin{array}{l}\text { Positive } \\
\text { cluster }\end{array}$ & & Symmetry & Multiplicity & $\mathrm{Li}-\mathrm{N}_{2}$ distance & $E_{\mathrm{b}}(\mathrm{eV})$ & $\begin{array}{l}\text { Neutral } \\
\text { cluster }\end{array}$ & & Symmetry & Multiplicity & $\mathrm{Li}-\mathrm{N}_{2}$ distance & $E_{\mathrm{b}}(\mathrm{eV})$ \\
\hline $\mathrm{Li}-\mathrm{N}_{2}^{+}$ & $1 \mathrm{~A}$ & $C_{\infty \mathrm{v}}$ & 1 & 2.069 & 0.57 & $\mathrm{Li}-\mathrm{N}_{2}$ & $1 \mathrm{~A}^{\prime}$ & $C_{2 \mathrm{v}}$ & 2 & 1.879 & -0.12 \\
\hline $\mathrm{Li}-\mathrm{N}_{6}^{+}$ & $3 \mathrm{~A}$ & $D_{3 \mathrm{~h}}$ & 1 & 2.093 & 0.51 & $\mathrm{Li}-\mathrm{N}_{6}$ & $3 A^{\prime}$ & $C_{2 \mathrm{v}}$ & 2 & 1.913 & 0.23 \\
\hline $\mathrm{Li}-\mathrm{N}_{8}{ }^{+}$ & $4 \mathrm{~A}$ & $T_{\mathrm{d}}$ & 1 & 2.102 & 0.49 & $\mathrm{Li}-\mathrm{N}_{8}$ & $4 A^{\prime}$ & $D_{4 \mathrm{~h}}$ & 2 & 2.022 & 0.26 \\
\hline $\mathrm{Li}-\mathrm{N}_{10}{ }^{+}$ & $5 \mathrm{~A}$ & $C_{4 \mathrm{v}}$ & 1 & $2.172^{a}$ & 0.45 & $\mathrm{Li}-\mathrm{N}_{10}$ & $5 A^{\prime}$ & $C_{1}$ & 2 & $2.165^{a}$ & -0.79 \\
\hline
\end{tabular}

with increasing number of $\mathrm{N}_{2}$ units. $\operatorname{LiN}_{8}^{+}$has a highly symmetrical structure with $T_{\mathrm{d}}$ symmetry. It also has high nitrogen content $(94.1 \%)$ and may be used as a potential precursor for production of poly-nitrogen species.

Among the low-lying isomers of $\operatorname{LiN}_{n}^{+/ 0}(n=2,4,6,8$, and 10) presented in Fig. 2 and 3, the end-on bound $\mathrm{N}_{2}$ units are the most common with the N-N bond lengths of approximately 1.09 $\AA$, which are nearly the same as those in isolated nitrogen molecules. The side-on bound $\mathrm{N}_{2}$ units are found in isomers $1 \mathrm{~A}^{\prime}$ and $2 \mathrm{~A}^{\prime}$, and the $\mathrm{N}-\mathrm{N}$ bonds in these clusters are clearly weakened by coordination and the $\mathrm{N}-\mathrm{N}$ bond lengths increase to approximately $1.16 \AA$. In addition, the isomers with a high number of $\mathrm{N}_{2}$ units commonly have relatively lower energies than those with the other all-nitrogen units. This is very similar to the results obtained in our previous studies. ${ }^{31,32}$

Other all-nitrogen groups, such as linear $\mathrm{N}_{3}$, circular $\mathrm{N}_{3}$, chain-shaped $\mathrm{N}_{4}$, circular $\mathrm{N}_{4}$, tetrahedral $\mathrm{N}_{4}$, circular $\mathrm{N}_{5}$, circular $\mathrm{N}_{6}$ and so on, were also found in the low-lying isomers of $\operatorname{LiN}_{n}{ }^{+/ 0}(n=2,4,6,8$, and 10) clusters. This suggests that the doping of lithium atom could promote the stability of the above all-nitrogen groups, and these energetic $\operatorname{LiN}_{n}^{+/ 0}(n=2,4,6,8$, and 10) isomers may exist in principle. Many $\mathrm{N}_{5}$ units found in $\mathrm{LiN}_{n}^{+/ 0}$ isomers were in the form of the $\eta^{1}-\mathrm{N}_{5}$ ring, which is consistent with the coordination mode of compounds synthesized to date such as $\left[\mathrm{M}\left(\mathrm{H}_{2} \mathrm{O}\right)_{4}\left(\mathrm{~N}_{5}\right)_{2}\right] \cdot 4 \mathrm{H}_{2} \mathrm{O}(\mathrm{M}=\mathrm{Mn}, \mathrm{Fe}$ and Co). ${ }^{53,54}$

\subsection{Binding energies of the most stable isomers}

To estimate the strength of the interactions between the Li atom and nitrogen ligands, we calculated the binding energies of the most stable isomers of $\operatorname{LiN}_{n}^{+/ 0}(n=2,4,6,8$, and 10). The calculation results are shown in Table 1 and Fig. 4 . The $\mathrm{Li}-\mathrm{N}_{2}$ distances in $\operatorname{LiN}_{n}^{+/ 0}(n=2,4,6,8$, and 10) are also listed in Table 1 for comparison.

An examination of the results presented in Table 1 and Fig. 4 shows that binding energies of the ground states of $\operatorname{LiN}_{n}^{+}(n=2$, $4,6,8$, and 10) are positive, suggesting a substantial energy stabilization of the $\operatorname{LiN}_{n}^{+}(n=2,4,6,8$, and 10) species compared to the bare Li cation and $\mathrm{N}_{2}$ molecules. The stabilizing effects decrease slowly as the numbers of end-on bound $\mathrm{N}_{2}$ units increase. Considering that the $\mathrm{N}-\mathrm{N}$ distances in the $\mathrm{N}_{2}$ units of $\operatorname{LiN}_{n}^{+}(n=2,4,6,8$, and 10) are all equal to that of the $\mathrm{N}_{2}$ molecules calculated in this work, we wish to stress that the calculated binding energies reflect the $\mathrm{Li}-\mathrm{N}_{2}$ bond strengths in the clusters. Moreover, as shown in Table 1, the $\mathrm{Li}-\mathrm{N}_{2}$ distances were found to be in the order of $\mathrm{LiN}_{2}{ }^{+}<\mathrm{LiN}_{4}{ }^{+}<\mathrm{LiN}_{6}{ }^{+}<\mathrm{LiN}_{8}{ }^{+}<$ $\mathrm{LiN}_{10}{ }^{+}$, which is consistent with the order of the binding energies.

For neutral $\operatorname{LiN}_{n}(n=2,4,6,8$, and 10) clusters, with the exception of the $1 \mathrm{~A}^{\prime}$ and $5 \mathrm{~A}^{\prime}$ clusters, the binding energies of the ground states are also positive, indicating the presence of similar stabilizing effects. However, for $1 \mathrm{~A}^{\prime}$ with only one sideon bound $\mathrm{N}_{2}$ unit, the binding energy is negative, possibly because the side-on bound $\mathrm{N}_{2}$ unit has a higher energy than the $\mathrm{N}_{2}$ molecule due to the weakening of the $\mathrm{N}-\mathrm{N}$ bond (1.168 $\left.\mathrm{A}\right)$. The binding energy of $5 \mathrm{~A}^{\prime}$ with $\mathrm{N}_{4}$ rings is also negative and is much lower than those of the other stable $\mathrm{Li}-\mathrm{N}$ isomers. This is because the energetic $\mathrm{N}_{4}$ ring drastically increases the relative energy of isomer $5 \mathrm{~A}^{\prime}$.

\subsection{NBO analyses for the most stable isomers of $\mathrm{LiN}_{n}^{+}$}

To further understand the binding and electronic structures of the $\mathrm{Li}-\mathrm{N}$ clusters observed in the mass spectra, we performed NBO analyses for the most stable isomers of $\operatorname{LiN}_{n}{ }^{+}(n=2,4,6,8$, and 10), and the calculated results are presented in Tables S1S5. $\dagger$ In the NBO model, the strength of the interaction of the electron donor and electron acceptor NBOs is defined by the stabilization energy $E(2)$. To evaluate the general contribution of all of the interactions between the electron donors and electron acceptors to the stabilization energy of the $\mathrm{LiN}_{n}{ }^{+}$clusters, the sum of all of the stabilization energies, $\sum E(2)$, was divided by

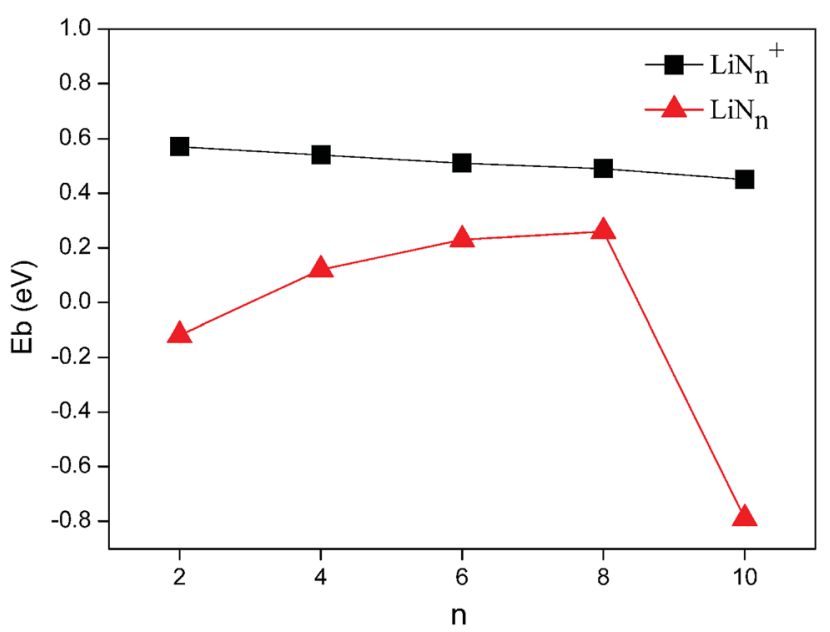

Fig. 4 Binding energies of the most stable isomers of $\operatorname{LiN}_{n}{ }^{+/ 0}(n=2,4$, 6,8 , and 10) clusters. 
Table 2 The NPA charge distributions and second-order perturbation stabilization energies of the most stable isomers of the $\mathrm{Li}^{+}-\left(\mathrm{N}_{\alpha} \equiv \mathrm{N}_{\beta}\right)_{n / 2}$ clusters

\begin{tabular}{|c|c|c|c|c|c|c|}
\hline Cluster & & $q(\mathrm{Li})$ & $q\left(\mathrm{~N}_{\alpha}\right)$ & $q\left(\mathrm{~N}_{\beta}\right)$ & Charge transfer & $\overline{E(2)}\left(\mathrm{kcal} \mathrm{mol}^{-1}\right)$ \\
\hline $\mathrm{Li}-\mathrm{N}_{2}^{+}$ & $1 \mathrm{~A}$ & 0.97607 & -0.19289 & 0.21682 & $\mathrm{LP}(1) \mathrm{N}_{\alpha} \rightarrow \mathrm{LP}^{*} \mathrm{Li}$ & 8.93 \\
\hline $\mathrm{Li}-\mathrm{N}_{4}^{+}$ & $2 \mathrm{~A}$ & 0.89635 & -0.15482 & 0.20665 & $\mathrm{LP}(1) \mathrm{N}_{\alpha} \rightarrow \mathrm{LP}^{*} \mathrm{Li}$ & 22.65 \\
\hline $\mathrm{Li}-\mathrm{N}_{8}^{+}$ & $4 \mathrm{~A}$ & 0.59306 & -0.07581 & 0.17754 & $\mathrm{LP}(1) \mathrm{N}_{\alpha} \rightarrow \mathrm{LP}^{*} \mathrm{Li}$ & 50.48 \\
\hline \multirow[t]{2}{*}{$\mathrm{Li}-\mathrm{N}_{10}{ }^{+}$} & $5 \mathrm{~A}$ & 0.47380 & -0.05275 & 0.15651 & $\mathrm{BD}(1) \mathrm{Li}-\mathrm{N}_{\alpha} \rightarrow \mathrm{BD} *(1) \mathrm{Li}-\mathrm{N}_{\alpha}$ & 31.32 \\
\hline & & & -0.05449 & 0.16567 & & \\
\hline
\end{tabular}

the number of $\mathrm{N}_{2}$ units, as shown in eqn (III), to obtain the average stabilization energy, $\overline{E(2)}$. Table 2 shows the NPA charge distributions and average second-order perturbation stabilization energies of the most stable isomers of the $\mathrm{LiN}_{n}{ }^{+}$clusters.

Based on the NBO data, it was concluded that for $\operatorname{LiN}_{n}^{+}(n=$ $2,4,6,8)$, electrons are transferred from the lone pair (LP) on $\mathrm{N}_{\alpha}$ of every $\mathrm{N}_{2}$ unit to the empty orbital LP* of the lithium atom, $\mathrm{LP}(1) \mathrm{N}_{\alpha} \rightarrow \mathrm{LP} * \mathrm{Li}$, leading to a lowering in the average stabilization energy by $8.93,22.65,37.36$ and $50.48 \mathrm{kcal} \mathrm{mol}^{-1}$, respectively. Meanwhile, for $\mathrm{LiN}_{10}{ }^{+}$, the interaction is occurs mainly between the $\mathrm{Li}_{1}-\mathrm{N}_{2}, \mathrm{Li}_{1}-\mathrm{N}_{4}, \mathrm{Li}_{1}-\mathrm{N}_{6}$ and $\mathrm{Li}_{1}-\mathrm{N} 8$ bonds, and the electrons are transferred from the bonding orbital (BD) of the $\mathrm{Li}-\mathrm{N}_{\alpha}$ bonds to the antibonding orbital (BD*) of the other $\mathrm{Li}-\mathrm{N}_{\alpha}$ bonds, giving rise to the $\overline{E(2)}$ values of approximately 31.32 kcal mol ${ }^{-1}$. In both cases, the $\mathrm{N}_{\alpha}$ and $\mathrm{N}_{\beta}$ in $\mathrm{N}_{2}$ units carry negative and positive charges, respectively, forming a dipole that strongly interacts with $\mathrm{Li}^{+}$. The average stabilization energy, $\overline{E(2)}$, of $\mathrm{LiN}_{8}^{+}$is the highest among the $\operatorname{LiN}_{n}^{+}(n=2,4,6,8$, and 10) clusters, providing a partial explanation for the highest abundance of $\mathrm{LiN}_{8}{ }^{+}$in the mass spectra.

\section{Conclusions}

$\operatorname{LiN}_{n}^{+}(n=2,4,6,8$, and 10) clusters were generated by laser ablation. $\mathrm{LiN}_{8}{ }^{+}$is found to be the most abundant. Density functional calculations were conducted to search for the stable structures of $\operatorname{LiN}_{n}{ }^{+/ 0}$. The theoretical results show that the most stable isomers of $\operatorname{LiN}_{n}{ }^{+}(n=2,4,6,8$, and 10) are in the form of $\mathrm{Li}^{+}\left(\mathrm{N}_{2}\right)_{n / 2}$, and their structures evolve from one-dimensional linear type $\left(C_{\infty \mathrm{v}}, n=2 ; D_{\infty \mathrm{h}}, n=4\right)$, to two-dimensional branch type $\left(D_{3 \mathrm{~h}}, n=6\right)$ to three-dimensional tetrahedral $\left(T_{\mathrm{d}}\right.$, $n=8)$ and square pyramid $\left(C_{4 \mathrm{v}}, n=10\right)$ types. The calculated binding energies suggest a substantial energy stabilization of the $\operatorname{LiN}_{n}^{+}(n=2,4,6,8$, and 10) species compared to the bare $\mathrm{Li}$ cation and $\mathrm{N}_{2}$ molecules. Further NBO analyses show that the $\mathrm{N}_{2}$ units in $\mathrm{LiN}_{n}{ }^{+}$are actually dipoles that could interact with $\mathrm{Li}^{+}$ effectively, and $\mathrm{LiN}_{8}^{+}$has the highest average stabilization energy. For neutral $\operatorname{LiN}_{n}(n=2,4,6$, and 8) clusters, the most stable isomers were also formed by a $\mathrm{Li}$ atom and the corresponding number of $\mathrm{N}_{2}$ units, while the most stable isomer of $\mathrm{LiN}_{10}$ is in the form of $\mathrm{Li}^{+}\left(\mathrm{N}_{2}\right)_{3}\left(\eta^{1}-\mathrm{N}_{4}\right)$.

\section{Conflicts of interest}

There are no conflicts to declare.

\section{Acknowledgements}

This work was supported by the National Natural Science Foundation of China (Grant No. 21103202 and 21273246).

\section{Notes and references}

1 W. J. Lauderdale, J. F. Stanton and R. J. Bartlett, J. Phys. Chem., 1992, 96, 1173-1178.

2 H. Östmark, New Trends in Research of Energetic Materials Czech Republic, 2006, pp. 231-250.

3 P. C. Samartzis and A. M. Wodtke, Int. Rev. Phys. Chem., 2006, 25, 527-552.

4 M. N. Glukhovtsev, H. Jiao and P. v. R. Schleyer, Inorg. Chem., 1996, 35, 7124-7133.

5 K. O. Christe, W. W. Wilson, J. A. Sheehy and J. A. Boatz, Angew. Chem., Int. Ed., 1999, 38, 2004-2009.

6 F. Cacace, G. de Petris and A. Troiani, Science, 2002, 295, 480481.

7 A. Vij, J. G. Pavlovich, W. W. Wilson, V. Vij and K. O. Christe, Angew. Chem., Int. Ed., 2002, 41, 3051-3054.

8 L. Gagliardi and P. Pyykkö, J. Phys. Chem. A, 2002, 106, 46904694.

9 G. von Zandwijk, R. A. J. Janssen and H. M. Buck, J. Am. Chem. Soc., 1990, 112, 4155-4164.

10 Q. S. Li and L. P. Cheng, J. Phys. Chem. A, 2003, 107, 28822889.

11 L. P. Cheng and Q. S. Li, J. Phys. Chem. A, 2005, 109, 31823186.

12 J. M. Mercero, J. M. Matxain and J. M. Ugalde, Angew. Chem., Int. Ed., 2004, 43, 5485-5488.

13 L. Jin and Y.-h. Ding, J. Phys. Chem. A, 2009, 113, 1364513650.

14 A. C. Tsipis and A. T. Chaviara, Inorg. Chem., 2004, 43, 12731286.

15 M. Lein, Chem.-Eur. J., 2001, 7, 4155-4163.

16 R. Haiges, J. A. Boatz, S. Schneider, T. Schroer, M. Yousufuddin and K. O. Christe, Angew. Chem., Int. Ed., 2004, 43, 3148-3152.

17 R. Haiges, J. A. Boatz, T. Schroer, M. Yousufuddin and K. O. Christe, Angew. Chem., Int. Ed., 2006, 45, 4830-4835.

18 R. Haiges, J. A. Boatz, M. Yousufuddin and K. O. Christe, Angew. Chem., Int. Ed., 2007, 46, 2869-2874.

19 R. Haiges, J. A. Boatz and K. O. Christe, Angew. Chem., Int. $E d .$, 2010, 49, 8008-8012. 
20 R. Haiges, J. A. Boatz, R. Bau, S. Schneider, T. Schroer, M. Yousufuddin and K. O. Christe, Angew. Chem., Int. Ed., 2005, 44, 1860-1865.

21 A. C. Filippou, P. Portius, D. U. Neumann and K.-D. Wehrstedt, Angew. Chem., Int. Ed., 2000, 39, 4333-4336.

22 P. Portius, A. C. Filippou, G. Schnakenburg, M. Davis and K.-D. Wehrstedt, Angew. Chem., Int. Ed., 2010, 49, 8013-8016.

23 A. C. Filippou, P. Portius and G. Schnakenburg, J. Am. Chem. Soc., 2002, 124, 12396-12397.

24 A. Villinger and A. Schulz, Angew. Chem., Int. Ed., 2010, 49, 8017-8020.

25 C. Knapp and J. Passmore, Angew. Chem., Int. Ed., 2004, 43, 4834-4836.

26 T. M. Klapötke, B. Krumm, M. Scherr, R. Haiges and K. O. Christe, Angew. Chem., Int. Ed., 2007, 46, 8686-8690.

27 T. M. Klapötke, B. Krumm, P. Mayer and I. Schwab, Angew. Chem., Int. Ed., 2003, 42, 5843-5846.

28 E. D. Pillai, T. D. Jaeger and M. A. Duncan, J. Am. Chem. Soc., 2007, 129, 2297-2307.

29 E. D. Pillai, T. D. Jaeger and M. A. Duncan, J. Phys. Chem. A, 2005, 109, 3521-3526.

30 A. D. Brathwaite, H. L. Abbott-Lyon and M. A. Duncan, J. Phys. Chem. A, 2016, 120, 7659-7670.

31 K. W. Ding, X. W. Li, H. G. Xu, T. Q. Li, Z. X. Ge, Q. Wang and W. J. Zheng, Chem. Sci., 2015, 6, 4723-4729.

32 K. W. Ding, H. G. Xu, Y. Yang, T. Q. Li, Z. Q. Chen, Z. X. Ge, W. L. Zhu and W. J. Zheng, J. Phys. Chem. A, 2018, 122, 46874695.

33 A. M. Sapse and P. V. R. Schleyer, Lithium Chemistry: Theoretical and Experimental Overview, Wiley Interscience, New York, USA, 1995.

34 D. Hao, J. Liu and J. Yang, J. Phys. Chem. A, 2008, 112, 1011310119.

35 T. B. Tai and M. T. Nguyen, Chem. Phys. Lett., 2010, 492, 290296.

36 L. F. Gong, W. L. Guo, X. M. Wu and Q. S. Li, Chem. Phys. Lett., 2006, 429, 326-331.

37 X. An, H. Zhuo, W. Tian, Q. Li, W. Li and J. Cheng, Mol. Phys., 2014, 112, 2954-2962.

38 Q. S. Li and L. P. Cheng, J. Phys. Chem. A, 2003, 107, 28822889.

39 M. N. Glukhovtsev, P. v. R. Schleyer and C. Maerker, J. Phys. Chem., 1993, 97, 8200-8206.

40 Y. C. Zhao, Z. G. Zhang, J. Y. Yuan, H. G. Xu and W. J. Zheng, Chin. J. Chem. Phys., 2009, 22, 655-662.
41 M. J. Frisch, G. W. Trucks, H. B. Schlegel, G. E. Scuseria, M. A. Robb, J. R. Cheeseman, G. Scalmani, V. Barone, B. Mennucci, G. A. Petersson, H. Nakatsuji, M. Caricato, X. Li, H. P. Hratchian, A. F. Izmaylov, J. Bloino, G. Zheng, J. L. Sonnenberg, M. Hada, M. Ehara, K. Toyota, R. Fukuda, J. Hasegawa, M. Ishida, T. Nakajima, Y. Honda, O. Kitao, H. Nakai, T. Vreven, J. A. Montgomery Jr, J. E. Peralta, F. Ogliaro, M. Bearpark, J. J. Heyd, E. Brothers, K. N. Kudin, V. N. Staroverov, R. Kobayashi, J. Normand, K. Raghavachari, A. Rendell, J. C. Burant, S. S. Iyengar, J. Tomasi, M. Cossi, J. M. M. N. Rega, M. Klene, J. E. Knox, J. B. Cross, V. Bakken, C. Adamo, J. Jaramillo, R. Gomperts, R. E. Stratmann, O. Yazyev, A. J. Austin, R. Cammi, C. Pomelli, J. W. Ochterski, R. L. Martin, K. Morokuma, V. G. Zakrzewski, G. A. Voth, P. Salvador, J. J. Dannenberg, S. Dapprich, A. D. Daniels, O. Farkas, J. B. Foresman, J. V. Ortiz, J. Cioslowski and D. J. Fox, Gaussian 09, Revision A.02, Gaussian, Inc., Wallingford, CT, 2009.

42 Y. Zhao and D. G. Truhlar, Theor. Chem. Acc., 2008, 120, 215241.

43 R. Huenerbein, B. Schirmer, J. Moellmann and S. Grimme, Phys. Chem. Chem. Phys., 2010, 12, 6940-6948.

44 CRC Handbook of Chemistry and Physics, ed. W. M. Haynes, 95th edn, 2014-2015.

45 A. E. Reed, L. A. Curtiss and F. Weinhold, Chem. Rev., 1988, 88, 899-926.

46 M. N. Glukhovtsev, H. Jiao and P. v. R. Schleyer, Inorg. Chem., 1996, 35, 7124-7133.

47 M. T. Nguyen, Coord. Chem. Rev., 2003, 244, 93-113.

48 A. Korkin, A. Balkova, R. J. Bartlett, R. J. Boyd and P. R. Schleyer, J. Phys. Chem., 1996, 100, 5702.

49 L. Gagliardi and P. Pyykko, J. Phys. Chem. A, 2002, 106, 46904694.

50 M. Lein, J. Frunzke, A. Timoshkin and G. Frenking, Chem.Eur. J., 2001, 7, 4155-4163.

51 L. Jin and Y. Ding, J. Phys. Chem. A, 2009, 113, 13645-13650.

52 S. Fau, K. J. Wilson and R. J. Bartlett, J. Phys. Chem. A, 2002, 106, 4639-4644.

53 Y. Xu, Q. Wang, C. Shen, Q. Lin, P. Wang and M. Lu, Nature, 2017, 549, 78-81.

54 C. Zhang, C. Yang, B. Hu, C. Yu, Z. Zheng and C. Sun, Angew. Chem., Int. Ed., 2017, 56, 1-4. 